\title{
Evaluation of functional and morphological parameters in eyes with primary congenital glaucoma after trabeculectomy in the long-term follow-up
}

\section{Ocena czynnościowych i morfologicznych parametrów w oczach z pierwotną jaskrą wrodzoną poddanych trabekulektomii w obserwacji długoterminowej}

\author{
Bronisława Koraszewska-Matuszewska', Małgorzata Nita' ${ }^{2}$ Andrzej Grzybowski3 ${ }^{3.4}$ \\ Independent Ophthalmic Practice, Katowice, Poland \\ Head: Professor Bronisława Koraszewska-Matuszewska, PhD, MD \\ 2 DiLMed Primary and Specialist Care Centre, Katowice, Poland \\ Head: Lucyna Strzelczak, MD \\ 3 Institute for Research in Ophthalmology, Poznan, Poland \\ Head: Professor Andrzej Grzybowski, PhD, MD \\ 4 Department of Ophthalmology, University of Warmia and Mazury, Olsztyn, Poland \\ Head: Professor Andrzej Grzybowski, PhD, MD
}

Ahstract: $\quad$ Aim: Primary congenital glaucoma is the most prevalent type of primary paediatric glaucoma. The aim of the study was to estimate functional and morphological parameters in eyes with primary congenital glaucoma, with and without Haab's striae, after classic trabeculectomy in the long-term follow-up.

Material and methods: 41 eyes of 27 children aged 7 days to 12 months at primary trabeculectomy with (group I) and without Haab's striae (group II) were reviewed. The best corrected visual acuity, intraocular pressure, central corneal thickness, axial biometry, corneal horizontal diameter, refraction, central endothelial cell density, cup-to-disc ratio, and perimetric mean deviation were analysed.

Results: The mean follow-up was 11.4 years. The mean age of operated infants was 5.65 months (group I) and 4.41 months (group II). The mean intraocular pressure before trabeculectomy was significantly higher and endothelial cell density was significantly lower in group I than in group II. The mean myopic refractive error was significantly higher in group I than in group II. There was no difference in best corrected visual acuity, central corneal thickness, axial biometry, corneal horizontal diameter, and perimetric mean deviation between the two groups.

Conclusions: The visual function in patients with primary congenital glaucoma after successful trabeculectomy performed in infancy is satisfactory, despite the presence of Haab's striae, impaired corneal structure and decreased endothelial cell density. High intraocular pressure before treatment is an important risk factor for the development of Haab's striae.

Classic trabeculectomy is a good first-line surgical procedure in the treatment of primary congenital glaucoma with and without Haab's striae.

Key words: $\quad$ primary congenital glaucoma, Haab's striae, trabeculectomy, visual function, long term follow-up.

Ahstrakt: $\quad$ Cel: pierwotna jaskra wrodzona to najczęstsza jaskra u dzieci. Celem pracy jest ocena czynnościowych i morfologicznych parametrów w oczach z pierwotna jaskra wrodzona, z liniami Haaba i bez nich, po klasycznej trabekulektomii w obserwacji długoterminowej.

Materiał i metody: analizie poddano 41 oczu 27 dzieci z liniami Haaba (grupa I) i bez linii Haaba (grupa II), u których wykonano pierwotną trabekulektomię w okresie od 7. dnia do 12. miesiąca życia dziecka. Analizowano najlepiej skorygowaną ostrość wzroku, ciśnienie wewnątrzgałkowe, centralną grubość rogówki, długość gałki ocznej, średnicę rogówki, refrakcję, liczbę komórek śródbłonka, stosunek wielkości wnęki do powierzchni tarczy i perymetryczne średnie odchylenie.

Wyniki: średni czas obserwacji wyniósł 11,4 roku. Średni wiek operowanych dzieci wyniósł 5,65 miesiąca (grupa I) i 4,41 miesiąca (grupa II). Średnie przedoperacyjne ciśnienie wewnątrzgałkowe było istotnie wyższe w oczach z grupy I. Średnia wartość krótkowzroczności była istotnie większa w oczach z grupy I. Najlepiej skorygowana ostrość wzroku, centralna grubość rogówki, długość gałki ocznej, średnica rogówki i perymetryczne średnie odchylenie nie różnicowały analizowanych grup.

Wnioski: ostrość wzroku w oczach z pierwotną jaskrą wrodzoną operowanych w okresie niemowlęctwa jest satysfakcjonująca pomimo obecności linii Haaba, zmian strukturalnych rogówki i zmniejszonej gęstości komórek śródbłonka.

Wysokie przedoperacyjne ciśnienie wewnątrzgałkowe jest istotnym czynnikiem ryzyka powstania linii Haaba w oczach zajętych pierwotną jaskrą wrodzoną.

Klasyczna trabekulektomia jest dobrą metodą z wyboru w chirurgicznym leczeniu pierwotnej jaskry wrodzonej z liniami Haaba i bez nich.

Stowa kluczowe: pierwotna jaskra wrodzona, linie Haaba, trabekulektomia, czynność widzenia, długoterminowy okres obserwacji.

The authors declare no conflict of interest/ Autorzy zgłaszają brak konfliktu interesów w związku $\mathbf{z}$ publikowaną pracą 
Primary congenital glaucoma (PCG) due to trabeculodysgenesis (abnormal development of the trabecular meshwork) is the most prevalent type of primary paediatric glaucoma. This rare eye disorder accounts for $0.01-0.04 \%$ of total blindness. PCG incidence varies by population and in Western developed countries it is approximately 1 in 10.000 births (1).

PCG generally presents clinically as a classic triad of photophobia, blepharospasm and epiphora secondary to an increase in intraocular pressure (IOP), which stimulates corneal nerves and causes pain (1). The standardized definition of PCG by the Childhood Glaucoma Research Network requires 2 or more of the following criteria to be met: IOP $>21 \mathrm{~mm} \mathrm{Hg}$, optic disc cupping, corneal findings (horizontal, diagonal or curvilinear Haab's striae, i.e. scarified breaks in Descemet's membrane, corneal edema, or diameter $>11 \mathrm{~mm}$ in newborns, $>12 \mathrm{~mm}$ in infants below 1 year of age, or $>13 \mathrm{~mm}$ at any age), ocular enlargement by progressive myopia or axial length out of keeping with normal growth, or a visual field defect consistent with glaucoma (2). Medical therapy has a limited role and surgery remains the primary therapeutic modality in PCG as a long-term solution for controlling IOP over time (1-4). The overall therapeutic success after surgery in paediatric glaucoma is variable, depending on the surgical technique and the severity of the disease. In early and advanced PCG, different goniosurgery methods (goniotomy, trabeculotomy, trabeculectomy without/with antimetabolite mitomycin C, combined trabeculotomy-trabeculectomy, glaucoma drainage devices and cyclodestructive procedures) are recommended $(1,4)$.

The aim of this study was to determine the functional and morphological parameters of PCG, with and without Haab's striae, after early, primary classic trabeculectomy in the long-term follow-up.

\section{Material and methods}

The research was carried out at the Department of Paediatric Ophthalmology, Independent Public Clinical Hospital Number 5 (current name: University Centre for Ophthalmology and Oncology), Medical University of Silesia, Katowice, Poland.

Ethics approval of research: This research adhered to the tenets of the Declaration of Helsinki. Informed consent of subjects/ guardians was obtained.

This retrospective study included 41 eyes of 17 boys and 10 girls with PCG treated by early, primary classic trabeculectomy between 1979 and 2001. Eyes were divided, based on the presence or absence of Haab`s striae, in order to estimate its influence on the visual acuity in long term follow-up, into group I, consisting of 15 eyes of boys and 8 eyes of girls with central and paracentral (between 3 and $6 \mathrm{~mm}$ from the optical axis) Haab's striae, and group II, consisting of 11 eyes of boys and 7 eyes of girls without Haab's striae.

Fourteen children had bilateral PCG, and in such cases both eyes were included in the analysis. Out of them, eleven children ( 6 boys, 5 girls) had unilateral Haab's striae and two boys had bilateral Haab's striae, differing in number and morphology. Additionally, one boy without Haab's striae had more advanced glaucoma in the left eye (more severe corneal oedema, larger corneal diameter and ocular axial length). Out of 13 children with unilateral PCG, 8 children ( 5 boys, 3 girls) had affected eye allocated to group I and 5 children ( 3 boys, 2 girls) had affected eye allocated to group II.

All subjects underwent a trabeculectomy with limbal-based flap and basal iridectomy without antifibrotic agents under halothane general anaesthesia at the age of 7 days to 12 months. A two-step procedure was performed in children with bilateral PCG approximately 1 month apart. All infants underwent surgery immediately after the diagnosis, thus all subjects were treatment naïve. Where patient cooperation was possible, best corrected visual acuity (BCVA) was measured using Snellen or logMAR charts after surgery from about 18 months of age. IOP was measured under general anaesthesia with the use of a handheld Perkins applanation tonometer providing preoperative (IOP-1) and postoperative (IOP-2) values. As patient cooperation improved with age, IOP was measured using a Goldmann applanation tonometer. Central corneal thickness (CCT) was measured using an ultrasound pachymeter (DGH 550 Pachette 2; DGH Technology, Exton, PA, USA) after 2001 (due its earlier inavailability). Ocular axial length was measured during an ocular ultrasound (Ultrascan $A+B$; Alcon Laboratories Inc., Fort Worth, TX, USA) pre- and postoperatively. The horizontal corneal diameter was measured before surgery under general anaesthesia using Castroviejo calipers. Corneal oedema precludes using devices which only work with clear cornea, so refraction was measured postoperatively in cooperating children and in adults using the autorefractometer (Auto Kerato-Refractometer KR 8900; Topcon, Tokyo, Japan). Central corneal endothelial cell density was measured in adults at the end of the long-term follow-up using the endothelial cell counter (SPO2; C.S.0., Scandicci Firenze, Italy). The cup-to-disc (C/D) ratio was evaluated in ophthalmoscopy; the first measurement was performed before surgery under general anaesthesia and the subsequent measurements in an outpatient setting with direct or indirect ophthalmoscopy. C/D grading was determined from clinical evaluation and notation. As the subject cooperation improved with age, the optic disc was assessed postoperatively using confocal scanning laser ophthalmoscopy (TopSS; Lasers Diagnostic Technologies, Inc., San Diego, CA, USA) and automated static perimetry (Octopus 1-2-3; Haag Streit AG, Koeniz, Switzerland). Three TopSS topographic parameters - total disc area, $C / D$ ratio and neuroretinal rim area - as well as perimetric mean deviation (MD) were analysed.

Infants with megalocornea and high myopia without PCG, corneal changes caused by birth trauma, corneal dystrophy, interstitial keratitis, Axenfeld-Rieger syndrome, Peter's anomaly, Sturge-Weber syndrome, neurofibromatosis, aniridia and infants after congenital cataract surgery were excluded. A Mann-Whitney U-test $(p=.05)$ was performed to compare groups of patients in relation to the measured parameters.

\section{Results}

Follow-up ranged between 4 and 31 years (mean 11.4 years). The values of the parameters measured in both groups shows Table I.

There was no difference in the age at surgery between subjects with and without Haab's striae. The first BCVA measurements were performed in children from about 18-th month of life. At the end of the long-term follow-up, there was no difference 


\begin{tabular}{|c|c|c|c|}
\hline & $\begin{array}{l}\text { Group I ( } n=23 \text { eyes) } \\
\text { with Haab's striae }\end{array}$ & $\begin{array}{l}\text { Group II ( } n=18 \text { eyes) } \\
\text { without Haab's striae }\end{array}$ & $\mathbf{P}$ \\
\hline Age at primary surgery (months) & $\begin{array}{c}1-11 \\
\text { Mean } 5.65 \pm 1.38\end{array}$ & $\begin{array}{c}0.23-12 \\
\text { Mean } 4.41 \pm 1.76\end{array}$ & .24 \\
\hline Postoperative* BCVA & $\begin{array}{c}0.01-1.0 \\
\text { Mean } 0.57 \pm 0.16\end{array}$ & $\begin{array}{c}0.1-1.0 \\
\text { Mean } 0.56 \pm 0.15\end{array}$ & .39 \\
\hline Preoperative IOP (IOP-1, mmHg) & $\begin{array}{c}32-50 \\
\text { Mean } 39.47 \pm 2.18\end{array}$ & $\begin{array}{c}24-41 \\
\text { Mean } 31.1 \pm 2.31\end{array}$ & $<.001$ \\
\hline Postoperative* IOP (IOP-2, mmHg) & $\begin{array}{c}14-21 \\
\text { Mean } 16.82 \pm 1.30\end{array}$ & $\begin{array}{c}15-22 \\
\text { Mean } 18.22 \pm 2.14\end{array}$ & .22 \\
\hline Postoperative* CCT $(\mu \mathrm{m})$ & $\begin{array}{c}440-630 \\
\text { Mean } 524.3 \pm 43.0\end{array}$ & $\begin{array}{c}478-603 \\
\text { Mean } 539.5 \pm 38.4\end{array}$ & .15 \\
\hline $\begin{array}{c}\text { Preoperative } \\
\text { and postoperative* biometry }(\mathrm{mm})\end{array}$ & $\begin{array}{l}17.0-24.7 \\
\text { Mean } 21.19 \pm 2.32 \\
16.50-29.63 \\
\text { Mean } 24.30 \pm 3.23\end{array}$ & $\begin{array}{c}17.0-25.98 \\
\text { Mean } 21.73 \pm 1.89 \\
20.23-29.99 \\
\text { Mean } 23.30 \pm 2.16\end{array}$ & $\begin{array}{l}.34 \\
.59\end{array}$ \\
\hline Preoperative corneal horizontal diameter $(\mathrm{mm})$ & $\begin{array}{c}10-14 \\
\text { Mean } 13.21 \pm 0.51\end{array}$ & $\begin{array}{c}12-14 \\
\text { Mean } 13.05 \pm 0.36\end{array}$ & .61 \\
\hline $\begin{array}{l}\text { Postoperative refraction measured in childhood } \\
\text { and at the end of the follow-up, spherical equivalent }\end{array}$ & $\begin{array}{l}-7.50-1.75 \\
\text { Mean }-2.29 \pm 2.79 \\
-13.50-1.75 \\
\text { Mean }-3.58 \pm 3.62\end{array}$ & $\begin{array}{l}-12.00-3.75 \\
\text { Mean }-0.77 \pm 2.71 \\
-13.00-3.75 \\
\text { Mean }-1.40 \pm 3.58\end{array}$ & .03 \\
\hline Postoperative* central corneal endothelial cell density $\left(\mathrm{mm}^{2}\right)$ & $\begin{array}{c}900-2900 \\
\text { Mean } 1413.26 \pm 233.49\end{array}$ & $\begin{array}{c}1428-2976 \\
\text { Mean } 2205.61 \pm 215.85\end{array}$ & $<.001$ \\
\hline $\begin{array}{l}\text { No. of patients with } \mathrm{C} / \mathrm{D} \text { ratio of } \leq 0.3 \text { assessed } \\
\text { in pre- and postoperatively* in ophthalmoscopy }\end{array}$ & 19 & 15 & .72 \\
\hline $\begin{array}{c}\text { Postoperative TopSS parameters: } \\
\text { TA, mm² } \\
\text { C/D ratio: initial } \\
\text { and follow-up* measurement } \\
\text { NRA: initial } \\
\text { and follow-up* measurement (mm²) }\end{array}$ & $\begin{array}{c}\text { Mean } 1.87 \pm 0.33 \\
\text { Mean } 0.33 \pm 0.22 \\
0.35 \pm 0.23 \\
\text { Mean } 1.26 \pm 0.40 \\
1.21 \pm 0.38\end{array}$ & $\begin{array}{c}\text { Mean } 2.44 \pm 0.26 \\
\text { Mean } 0.46 \pm 0.21 \\
0.46 \pm 0.22 \\
\text { Mean } 1.18 \pm 0.50 \\
1.15 \pm 0.47\end{array}$ & $\begin{array}{l}<.001 \\
.02 \\
.07 \\
.29 \\
.34\end{array}$ \\
\hline $\begin{array}{l}\text { Postoperative MD: } \\
\text { initial } \\
\text { and follow-up* measurement }(\mathrm{dB})\end{array}$ & $\begin{array}{c}\text { Mean } 8.80 \pm 8.84 \\
10.59 \pm 11.80\end{array}$ & $\begin{array}{l}\text { Mean } 8.26 \pm 7.85 \\
8.32 \pm 7.55\end{array}$ & $\begin{array}{l}.41 \\
.22\end{array}$ \\
\hline
\end{tabular}

BCVA - best corrected visual acuity/ najlepsza skorygowana ostrość wzroku; IOP - intraocular pressure/ ciśnienie wewnq̨irzgałkowe; CCT - central corneal thickness/ centralna grubość rogówki; C/D - cup-to-disc ratio/ współzzynnik wielkości zagłębienia do wielkości tarczy; TA - total disc area/ całkowita powierzchnia tarczy; NRA - neuroretinal rim area/ powierzchnia pierścienia nerwowo-siatkówkowego; MD - mean deviation/ średnie odchylenie perymetryczne ${ }^{*}$ measured at the end of the long-term follow-up/ pomiar pod koniec długotrwałej obserwacii.

Tab. I. Comparison of the parameters measured in patients with (group I) and without Haab's striae (group II) treated by early classic trabeculectomy. Tab. I. Zestawienie parametrów mierzonych u pacjentów z liniami Haaba (grupa I) i bez linii Haaba (grupa II) leczonych za pomocą wczesnej klasycznej trabekulektomii.

in the mean BCVA between the two groups. There was one eye with amblyopia and exotropia in group I and two such eyes in group II. The mean preoperative IOP was significantly higher in the group with Haab's striae, however, at the end of the follow-up there was no difference in mean IOP between the groups.

There was no difference between the groups in the mean central corneal thickness at the end of the follow-up as well as in axial biometry and corneal horizontal diameter both before trabeculectomy and at the end of the follow-up. Group I had a significantly higher mean degree of myopia (expressed as spherical equivalent) assessed both in childhood and at the end of follow-up (in adults) and a significantly lower mean central corneal endothelial cell density measured at the end of the follow-up. More patients in group I had the C/D ratio of .03 or below me- asured in ophthalmoscopy both before surgery and at the end of the follow-up. Two TopSS parameters, i.e. mean total disc area and C/D ratio, measured later in follow up in already adult patients were significantly higher in group II at the first assessment. At the end of follow up, though, there was no difference in TopSS C/D ratio betwen the groups. Similarly, there was no difference between the groups in TopSS neuronal rim area and MD of perimetry, both at the first assessment and at the end of the follow-up.

Trabeculectomy was uneventful in both groups. There was no new onset of Haab's striae or an increase in their number postoperatively. Anti-glaucoma drops were introduced 4-10 years after the primary surgery. In eyes with IOP above $30 \mathrm{mmHg}$ whilst on topical anti-glaucoma medications, the second trabe- 
culectomy was performed in 3 eyes from group I 2 eyes treated after 4.5 years and one after 7 years) and in 1 eye from group II (after 6 years). No antifibrotic agent or glaucoma drainage device was used. Additional topic anti-glaucoma medications were used in $56.5 \%$ of the eyes in group I and in $55.5 \%$ of the eyes in group II in the long-term follow-up.

\section{Discussion}

The age has been shown as an important prognostic factor in PCG $(5,6)$. Diagnosis before 2 month or after 2 years of age is associated with worse prognosis (6). Children diagnosed at below 3 months of age have a visual outcome of less than 20/200 (0.1) despite successful surgical glaucoma control (2). Worse outcome of trabeculectomy is also reported in younger patients (7). Among our subjects, there were infants diagnosed in the first and in the fourth day, as well as in the second month of life. Primary trabeculectomy was performed between the age of 7 days and 12 months in all eyes from both groups. Our results do not confirm poor prognosis associated with younger age at diagnosis or surgery in PCG patient and the outcomes are similar to results of other surgeons $(2,3,5,8)$.

PCG has the best prognosis of all types of paediatric glaucoma $(1,5)$, with $52 \%$ to $79 \%$ of patients achieving visual acuity of 20/50 (0.4) or better (1), and such postoperative visual acuity is estimated to be a good functional result in buphthalmic eyes $(9,10)$. We achieved comparable mean BCVA in patients with and without Haab's striae, which contrasts with the results of other authors who obtained worse visual outcomes in children with Haab's striae (11).

Significantly higher preoperative IOP (mean $39.47 \pm$ $2.18 \mathrm{mmHg}, \mathrm{p}=.000016$ ) in infants from group I confirms the critical role of this factor in corneal damage and development of Haab's striae. Early trabeculectomy successfully lowered IOP in both our groups, which is in keeping with the findings of other studies $(3,5,12)$. The mean postoperative IOP below $18 \mathrm{mmHg}$ achieved in group I is also comparable to the results of other studies (13).

Various authors consider axial length and corneal diameter to be important factors in diagnosis and monitoring of patients with PCG $(5,8)$. In our study, there was no difference in baseline axial length and corneal diameter between the groups. At the end of follow up, though, group I had significantly larger ocular axial length, which explains a higher degree of myopia in that group. Just as reported by other authors (14), the central corneal endothelial cell density was significantly lower in group I, which can be explained by higher preoperative IOP demonstrated in this group (15).

Optic disc assessment is crucial in diagnosis and monitoring of patients with glaucoma $(1,3,5,10-12)$. Confocal scanning laser ophthalmoscopy enables objective, quantitative, three-dimensional and reproducible analysis of the optic disc (16). Most patients from both groups had a normal optic disc as assessed in ophthalmoscopy both pre- and postoperatively; the $\mathrm{C} / \mathrm{D}$ ratio of 0.4 to 0.9 was demonstrated only in $18 \%$ of patients from group I and $16.7 \%$ of patients from group II. The mean TopSS C/D ratio did not exceed 0.5 and remained stable in both groups across a long-term follow-up. The initial TopSS C/D ratio was larger in patients from group II, who had a congenitally larger disc area and thus a proportionally higher $\mathrm{C} / \mathrm{D}$ ratio, as confirmed by Quigley (17). Intact optic nerve may explain good functional results achieved after trabeculectomy in both groups; especially in group I with Haab's striae, despite the simultaneous low endothelial cell density and corneal structural changes.

Surgery remains the primary therapeutic modality in PCG, however controversy exists as to the best procedure for the initial treatment of PCG $(1,12,13,18)$. Goniotomy and conventional trabeculotomy carried out by a surgeon experienced and skilful at both techniques offered transient effects and had to be repeated under anaesthesia. As the IOP did not stabilise, visual acuity decreased and the new Haab's striae formed, primary trabeculectomy started to be used in PCG and the experiences have been published since 1981 (19). Primary trabeculectomy in PCG is accepted by many surgeons and offers good results $(5,12,13,18,20)$. The reported success rate is $75 \%(20), 87 \%$ after a single procedure (13), and $92.3 \%(18)$. PCG control was maintained over a period of at least 5 years after primary trabeculectomy, which is higher than most reported series of goniotomy or trabeculotomy (18) without a high incidence of serious complications (20). Among our subjects, there were infants below 3 months of age at the time of surgery and with ocular axial length of $24 \mathrm{~mm}$, which proved to be the major risk factor for the failure of primary $a b$ externo surgery (21). Good results in terms of BCVA, IOP, uneventful peri- and postoperative course or the need to use antifibrotic agents or glaucoma drainage devices during a secondary procedure, achieved in both groups enable concluding that primary early trabeculectomy is a good first-line surgical option in PCG with and without Haab's striae, which offers long term stability, as confirmed by Rodrigues (follow-up from 2 to 19 years) (22), Fulcher (mean 7.89 years of follow-up) (18) and Burke (mean 3.9 years of follow-up) (13). All our patients were of white ethnicity, which is associated with a better prognosis for single trabeculectomy in PCG (18).

\section{Conclusions}

Treated early, eyes of patients with PCG, with and without Haab's striae, achieve good visual function, despite the presence of Haab's striae and decreased endothelial cell density. High preoperative IOP is an important risk factor for the Descemet's membrane rupture, its secondary scarification and Haab's striae formation. Classic trabeculectomy undertaken during the first 6 months of life and as the first surgical procedure is a good therapeutic option for PCG with and without Haab's striae, which offers long term stability.

\section{References:}

1. Mandal AK, Chakrabarti D: Update on congenital glaucoma. Indian J Ophthal. 2011; 59(7): 148-157.

2. Zagora SL, Funell ChL, Martin FJ, Smith JEH, Hing S, Billson FA, et al.: Primary Congenital Glaucoma Outcomes: Lessons From 23 Years of Follow-up. Am J Ophthalmol. 2015; 159(4): 789-796.

3. Yassin SA, Al-Tamimi ER: Surgical outcomes in children with primary congenital glaucoma: a 20-year experience. Eur J Ophthalmol. 2016; 26(6): 581-587. 
4. Ghate D, Wang X: Surgical interventions for primary congenital glaucoma. Cochrane Database Syst Rev. 2016; 1:CD008213. doi:10.1002/14651858.CD008213.pub2:1-54.

5. Moschos MM, Nitoda E, Fenzel I, Song X, Langenbucher A, Kaesmann B, et al.: Prognostic factors of pediatric glaucoma: a retrospective study. Int Ophthalmol, Springer 2018; https://doi. org/10.1007/s10792-018-0819-0:1-15.

6. Haas J: Principles and problems of therapy in congenital glaucoma. Invest Ophthalmol. 1968; 7: 140-146.

7. Sturmer J, Broadway DC, Hitchings RA: Young patient trabeculectomy: Assessment of risk factors for failure. Ophthalmology. 1993; 100: 928.

8. Cronemberger S, Calixto N, Milhomens TGA, Gama PO, Milhomens EG, Rolim $\mathrm{H}$, et al.: Effect of intraocular pressure control on central corneal thickness, horizontal corneal diameter, and axial length in primary congenital glaucoma. J AAPOS. 2014; 18: 433-436.

9. Yassin SA: Long-term visual outcomes in children with primary congenital glaucoma. Eur J Ophthalmol. 2017; doi: 10.5301/ ejo.5000976:1-7.

10. Mendicino ME, Lynch MG, Drack A, Beck AD, Harbin T, Pollard Z, et al.: Long-term surgical and visual outcomes in primary congenital glaucoma: 360 degrees trabeculotomy versus goniotomy. J AAPOS. 2000; 4(4): 205-210.

11. Patil B, Tandon R, Sharma N, Verma M, Upadhyay AD, Gupta V, et al.: Corneal changes in childhood glaucoma. Ophthalmology. 2015; 122: 87-92.

12. Alsheikheh A, Klink J, Klink T, Steffen H, Grehn F: Long-term results of surgery in childhood glaucoma. Graefe`s Arch Clin Exp Ophthalmol. 2007; 245: 195-203.

13. Burke JP, Bowel R: Primary trabeculectomy in congenital glaucoma congenital glaucoma. Br J Ophthalmol. 1989; 73: 186.
14. Mastropasqua L, Carpineto $P$, Ciancaglini M, Nubile M, Doronzo E: In vivo confocal microscopy in primary congenital glaucoma with megalocornea. J Glaucoma. 2002; 11: 83-89.

15. Oberacher-Velten J, Prasser Ch, Lorenz B: Evolution of central corneal thickness in children with congenital glaucoma requiring glaucoma surgery. Graefes Arch Clin Exp Ophthalmol. 2008; 246: 397-403.

16. Byoung-Sun A, Changwon K: Ability of a confocal scanning laser ophthalmoscope (TopSS) to detect early glaucomatous visual field defect. Br J Ophthalmol. 2000; 84: 852-855.

17. Quigley HA, Brown AE, Morrison JD, Drance SM: The size and shape of the optic disc in normal human eyes. Arch Ophthalmol 1990; 100: 51-57.

18. Fulcher T, Chan J, Lanigan B, Bowell R, O'Keefe M: Long term follow up of primary trabeculectomy for infantile glaucoma. $\mathrm{Br} \mathrm{J}$ Ophthalmol. 1996; 80: 499-502.

19. Koraszewska-Matuszewska B, Samochowiec-Donocik E: Trabeculectomia jako pierwszy zabieg w pierwotnej jaskrze wrodzonej/Primary trabeculectomy in primary congenital glaucoma. Klin Oczna. 2000; 102: 331-334.

20. Rao KV, Sai CM, Babu BV: Trabeculectomy in congenital glaucoma. Indian J Ophthalmol. 1984; 32: 439-440.

21. Dietlein TS, Jacobi PC, Krieglstein GK: Prognosis of primary ab externo surgery for primary congenital glaucoma. $\mathrm{Br} \mathrm{J}$ Ophthalmol. 1999; 83(3): 317-322.

22. Rodrigues AM, Paranhos A Jr., Montezano FT, de Arruda Melo PA, Prata J Jr.: Comparison between results of trabeculectomy in primary congenital glaucoma with and without the use of mitomycin C. J Glaucoma. 2004; 13(3): 228-232.

The paper was originally received 22.05.2016 (KO-00077-2016)/ Praca wpłynęła do Redakcji 22.05.2016 r. (KO-00077-2016) Accepted for publication 20.10.2018/

Zakwalifikowano do druku 20.10.2018 r.

Reprint requests to (Adres do korespondencji): Professor Andrzej Grzybowski, PhD, MD Jozef Strus Poznan City Hospital, Department of Ophthalmology 3 Szwajcarska St, 361-285 Poznań, Poland e-mail: ae.grzybowski@gmail.com 